\title{
The effect of starch-based biomaterials on leukocyte adhesion and activation in vitro
}

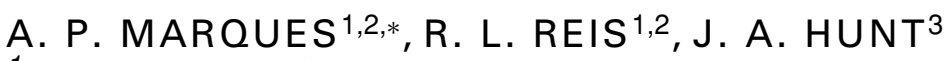 \\ ${ }^{1} 3$ B's Research Group, Biomaterials, Biodegradables, Biomimetics, University of Minho, \\ Campus de Gualtar, 4710-057 Braga, Portugal \\ E-mail:apmarques@dep.uminho.pt \\ ${ }^{2}$ Department of Polymer Engineering, University of Minho, Campus de Azurém, \\ 4810-058 Guimarães, Portugal \\ ${ }^{3}$ Clinical Engineering, UKCTE, University of Liverpool, L69 3GA, UK
}

Leukocyte adhesion to biomaterials has long been recognised as a key element to determine their inflammatory potential. Results regarding leukocyte adhesion and activation are contradictory in some aspects of the material's effect in determining these events. It is clear that together with the wettability or hydrophilicity/hydrophobicity, the roughness of a substrate has a major effect on leukocyte adhesion. Both the chemical and physical properties of a material influence the adsorbed proteins layer which in turn determines the adhesion of cells.

In this work polymorphonuclear (PMN) cells and a mixed population of monocytes/macrophages and lymphocytes (mononuclear cells) were cultured separately with a range of starch-based materials and composites with hydroxyapatite (HA). A combination of both reflected light microscopy and scanning electron microscopy (SEM) was used in order to study the leukocyte morphology. The quantification of the enzyme lactate dehydrogenase (LDH) was used to determine the number of viable cells adhered to the polymers. Cell adhesion and activation was characterised by immunocytochemistry based on the expression of several adhesion molecules, crucial in the progress of an inflammatory response.

This work supports previous in vitro studies with PMN and monocytes/macrophages, which demonstrated that there are several properties of the materials that can influence and determine their biological response. From our study, monocytes/macrophages and lymphocytes adhere in similar amounts to more hydrophobic (SPCL) and to moderately hydrophilic (SEVA-C) surfaces and do not preferentially adhere to rougher substrates (SCA). Contrarily, more hydrophilic surfaces (SCA) induced higher PMN adhesion and lower activation. In addition, the hydroxyapatite reinforcement induces changes in cell behaviour for some materials but not for others.

The observed response to starch-based biodegradable polymers was not significantly different from the control materials. Thus, the results reported herein indicate the low potential of the starch-based biodegradable polymers to induce inflammation especially the HA reinforced composite materials.

(C) 2005 Springer Science + Business Media, Inc.

\section{Introduction}

One of the major stages in the development of biomaterials is the assessment of the biological reactions resulting from their interaction with the living tissues [1-3]. Clinical deployment or application will trigger foreign body reactions that may, according to the severity, determine the success or failure of the device.

Cellular recruitment into the interface of tissue and device plays an important role in implant loosening.
The cell types that predominate in the implantation site during the different phases of inflammation are lymphocytes, monocytes and macrophages with polymorphonuclear neutrophils (PMN), in acute inflammation or infection $[4,5]$. These cells constitute appropriate systems to study, in vitro, the complex biological reactions of cell-material interactions and the release of chemotactic mediators that in vivo will control inflammatory responses. 
The mechanisms involved in the development of the inflammatory response are many and rather complex, but the activation of leukocytes leading to the up-regulation of adhesion molecules on the cell surface plays a central role and has been the focus of some recent studies $[6,7]$. Therefore it is of extreme importance to try to understand the mechanisms of leukocyte adhesion and it's relation with the activation state of the cells. Cells adhere by utilising three major groups of adhesion molecules [8]: Integrins, selectins and glycoproteins, for example members of the immunoglobulin superfamily. Cell-cell contacts formed by integrins contribute to activities such as antigen presentation, cytotoxicity, phagocytosis among others $[8,9]$. Integrins are constitutively expressed on leukocytes, but are only able to form adhesive contacts with other cells following activation to produce structural and affinity changes in the external integrin moieties [9].

Several adhesion molecules are known to play primordial roles in the inflammatory process, some of them previously used as specific cell-function markers were chosen to be identified in this study. The surface antigen known as lymphocyte function-related antigen (LFA-1), expressed in all leukocytes, is an integrin consisting of an $\alpha$ subunit, also defined as CD11a, and the $\beta_{2}$ subunit, denominated as CD18. The subunit $\alpha$ can vary in the heterodimer, originating two other important adhesion molecules, the CD11b or Mac-1 and CD11c, both expressed on monocytes/macrophages and granulocytes [10] but not on lymphocytes [11]. CD11a is involved in the adhesion of leukocytes to endothelium during inflammatory reactions and Mac-1 plays a key role in the adherence of both monocytes and neutrophils to vascular endothelium for subsequent extravasation [12]. CD11b/CD18 is also involved in a variety of cellcell and cell-substrate interactions such as attachment and phagocytosis of particles coated with C3bi by granulocytes and macrophages [13].

Integrins have as receptors, specific cell surface molecules belonging to the immunoglobulin (Ig) superfamily, which are expressed on endothelial cells. The $\beta_{2}$ integrins primarily recognise the intracellular adhesion molecule -1 (ICAM-1). In the mediation of cell adhesion, lymphocytes mainly use LFA-1 to interact with ICAM-1 whereas neutrophils appear to use both LFA-1 and Mac-1 to attach to ICAM-1 expressing cells. These are necessary interactions to stop leukocytes rolling along endothelium, enabling migration to the site of injury/inflammation [12]. ICAM-1 binds not only to leukocyte integrins but also to fibrinogen, which may be an important mechanism of recruiting inflammatory cells to places of injury.

Another feature of inflammation involves the expression of major histocompatibility complex (MHC). In particular, during the immune response to pathogens, antigen presenting cells process and present selected foreign peptides through the MHC class I or II on their surface [13]. The capacity of these molecules to avoid interactions between $\mathrm{T}$ cells and their accessory cells, has been demonstrated previously [14].

In the presence of biomaterials, however, the typical inflammatory process is different, since materials can determine the extent and duration. The general mechanism of surface dependent cellular responses is believed to be adhesion receptor binding to the surface specific adsorbed protein layer, which activates intracellular signal transduction pathways, resulting in a modification of cell behaviour [15]. Therefore, biomaterial surface physical and chemical characteristics directly or indirectly dictates cell adhesion and activation by determining the types, levels and conformations of adsorbed proteins [5].

Starch-based materials and composites have been proposed for a large range of biomedical applications [16-20]. These materials have shown promising properties in terms of cytocompatibility [21-23] which leads their evaluation further on to consider their immunogenic potential. The aim of the present study was to investigate the contribution of various types of starchbased materials and composites and respective changes in their chemical and physical properties in leukocyte adhesion and activation, namely in promoting differentiation of different subsets of macrophages in order to demonstrate the effect of these materials in terms of an immunogenic response.

\section{Materials and methods}

\subsection{Materials}

The materials studied were: (i) a 50/50 (wt\%) blend of corn starch and ethylene vinyl alcohol (SEVA-C, Novamont, Italy), (ii) SEVA-C reinforced with 10, 20 and $30 \%$ (wt) of hydroxyapatite (HA, Plasma Biotal, UK), (iii) a 50/50 (wt\%) blend of corn starch and cellulose acetate (SCA, Novamont, Italy), (iv) SCA reinforced with 10, 20 and 30\% (wt) of hydroxyapatite, (v) a 30/70 (wt\%) blend of corn starch and polycaprolactone (SPCL, Novamont, Italy) and (vi) SPCL reinforced with 10, 20 and 30\% (wt) of hydroxyapatite. In the composites the average size of $90 \%$ of the HA particles was found to be below $6.5 \mu \mathrm{m}$ (laser granulometry analysis).

Poly-L-Lactide (Purac biochem BV, The Netherlands), being the gold standard for biodegradables in biomedical applications, was used as a biodegradable control material. Borosilicate glass (BDH, England) and polystyrene coverslips (Sarstedt, Inc, USA) were used as experimental controls for assays involving neutrophils and monocytes/macrophages separately.

All the materials, both the polymers and the composites were processed into circular samples $(\varnothing 1 \mathrm{~cm})$ by injection moulding, under optimised processing conditions and sterilised by ethylene oxide $(\mathrm{EtO})$ in conditions that have been described previously [24].

\subsection{Neutrophil isolation}

Neutrophils were isolated from fresh heparinised peripheral human blood collected from healthy volunteers. Blood was mixed with a $6 \%$ dextran solution, settled and the supernatant layered onto lymphocyte separation medium and centrifuged at $2400 \mathrm{rpm}$ for $25 \mathrm{~min}$ at room temperature. The pellet was washed once with phosphate buffered saline (PBS) solution without 
calcium and magnesium and the remaining red blood cells were removed by water lysis. The cell suspension was washed twice with PBS without calcium and magnesium at $2400 \mathrm{rpm}$ for $5 \mathrm{~min}$ at room temperature. Cells were counted using a haemocytometer and kept at $4{ }^{\circ} \mathrm{C}$ until use.

\subsection{Mononuclear isolation (lymphocytes and monocytes/macrophages)}

A mixed population of lymphocytes and monocytes/macrophages was isolated from healthy human volunteers. Blood was layered onto lymphocyte separation medium (LymphoSep, ICN Biomedicals, USA) and centrifuged at $2400 \mathrm{rpm}$ for $25 \mathrm{~min}$ at $4{ }^{\circ} \mathrm{C}$. Cell suspension was washed twice with PBS at $2400 \mathrm{rpm}$ for $5 \mathrm{~min}$ at $4{ }^{\circ} \mathrm{C}$ and the final concentration set with Medium 199 (Gibco BRL, USA) supplemented with $1 \%$ of antibiotics (Sigma Chemical Co, USA), $10 \%$ of foetal calf serum (FCS, Gibco BRL, Life Technologies, USA) and $0.2 \%$ of fungizone (Sigma Chemical Co, USA).

\subsection{Adhesion and morphological analysis}

After isolation, neutrophils were seeded onto the materials at a concentration of $4 \times 10^{4}$ cells $/ \mathrm{ml}$ in $1.5 \mathrm{ml}$ of culture medium for $1 / 2,1$ and $4 \mathrm{~h}$ and stained with haematoxylin.

The mixed population of lymphocytes and monocytes/macrophages was also cultured in direct contact with the materials for 3,7 and 14 days, at a concentration of $4 \times 10^{4}$ cells $/ \mathrm{ml}$, in $1 \mathrm{ml}$ of the culture medium used to prepare the cell suspension.

After each time period, the cells were rinsed in PBS and fixed with gluteraldehyde $2.5 \%$ in PBS for $1 \mathrm{~h}$ at room temperature. After fixation the cells were rinsed with PBS, distilled water and dehydrated in graded ethanol solutions (70, 90, and 100\%) twice, $15 \mathrm{~min}$ each and critical point dried. Samples were chromium sputter coated (Emitech K575 X, UK) and observed on a Leo 1550 field emission SEM (Leo, UK).

\subsection{Lactate dehydrogenase quantification}

Mononuclear cells were seeded in direct contact with the polymers for 3,7 and 14 days at a concentration of $5 \times 10^{4}$ cells $/ \mathrm{ml}, 1.5 \mathrm{ml}$ per well. After each time period, materials were transferred to new culture plates together with $500 \mu \mathrm{l}$ of the culture supernatant and all the plates were frozen at $-80^{\circ} \mathrm{C}$ for approximately $60 \mathrm{~min}$ followed by thawing at $37^{\circ} \mathrm{C}$ for 60 $\min$. This freeze and thaw cycle was repeated 3 times. Supernatant $(50 \mu \mathrm{l})$ of each well was transferred to a new 96-well plate and the lactate dehydrogenase(LDH) kit (Promega, CytoTox96 ${ }^{\mathrm{TM}}$ ) was used to quantify the enzyme. The absorbance of the reaction product was recorded on a multiwell microplate reader at $490 \mathrm{~nm}$ within $1 \mathrm{~h}$. A standard curve was prepared with dilutions of an LDH standard versus absorbance readings in order to determine, the LDH Units of each sample. Each sample was tested in triplicate and in 4 separate experiments.

\subsection{Antibodies}

To identify individual leukocyte cell surface molecules the following mouse anti-human monoclonal antibodies were used: CD3 (reacts with $\varepsilon$-chain of the CD3/T-cell antigen receptor) and CD5 as T-lymphocyte markers (Pharmingen, USA), CD11a also known as lymphocyte associated antigen-1 (LFA-1) and expressed by all leukocytes (Pharmingen, USA), CD11b which reacts with Mac-1 and CD11c (Pharmingen, USA) as macrophage and monocyte markers, CD54 (Pharmingen, USA), which reacts with intracellular adhesion molecule-1 (ICAM-1) expressed in activated macrophages, CD68 (Dako A/S, Denmark) a marker for macrophages and HLA-DR antibody (Serotec, UK) which recognizes MHC II antigen present in activated macrophages.

\subsection{Immunocytochemistry}

After each time period materials with cells were washed twice in PBS, fixed with $4 \%$ formaldehyde, $2 \%$ sucrose solution in water for $30 \mathrm{~min}$ at room temperature, washed with PBS buffer and stained with the avidinbiotin alkaline phosphatase technique. Materials were exposed to rabbit serum for $30 \mathrm{~min}$ to reduce nonspecific reactivity, followed by primary antibodies for 1 $\mathrm{h}$ at room temperature. After that time materials were rinsed with PBS for $5 \mathrm{~min}$ and incubated with biotinylated rabbit anti-mouse IgG antibody (Dako A/S, Denmark) for $1 \mathrm{~h}$ at room temperature. The Avidin and Biotinylated horseradish peroxidase complex (Vector Laboratories Ltd., UK) was added to all materials for 1 $\mathrm{h}$ and the substrate reaction was developed using the Alkaline Phosphatase Substrate Kit (Vector Laboratories Ltd., UK). Each incubation, except the rabbit serum, was followed by one wash with PBS buffer for $5 \mathrm{~min}$. Materials were washed and counterstained with haematoxylin and mounted in permanent aqueous mounting medium (Serotec Ltd, UK). Each material had one sample stained as a control replacing the primary antibody with PBS buffer.

\subsection{Statistical analysis}

LDH data was averaged and the standard deviation is reported as a measure of sample variation. The data was statistically analysed by a one way ANOVA analysis using a Tukey-HDS test [25]. All the materials were compared between themselves and the control. If probability values were less than $0.05(p<0.05)$, differences observed for the two materials were considered statistically significant.

\section{Results}

\subsection{Cell adhesion and morphology 3.1.1. $P M N$}

Neutrophils were cultured in contact with the different materials and their morphology observed by reflected microscopy after haematoxylin staining. The control materials (PLLA as a biodegradable control and glass as the material which induces high PMN activation) showed reduced neutrophil adhesion with a very 
uniform round morphology. A qualitative microscopic comparison of the amount of cells on the surface of the materials was done. Comparing equivalent times of culture, the blend of starch-cellulose acetate (SCA) presented higher cell adhesion in contrast with the blend with polycaprolactone, which showed a low number of cells on their surfaces. Furthermore, while for SEVAC, SCA and respective composites the highest adhesion time was $2 \mathrm{~h}$ of culture, for SPCL and composites it was possible to observe more adherent cells after $4 \mathrm{~h}$ of culture (Fig. 1(a)-(c)).

The presence of ceramic resulted in different affinities, in terms of number of adherent cells, depend- ing on the blend. While starch-ethylene vinyl alcohol (SEVA-C) composites presented a tendency for low numbers of adherent cells, the surface of SCA composites seemed to promote cell adhesion and the reinforcement of SPCL did not show any significant adhesion effect (Fig. 1(d)-(f)).

The three starch-based biomaterials showed various cell morphologies depending on the type of blend, but morphology also changed in the presence of HA. Some neutrophils on the surface of SEVA-C adopted a spindly, elongated morphology suggestive of motility (Fig. 1(a)). However, in the presence of ceramic with $10 \% \mathrm{HA}$, the majority of the cells spread extensively

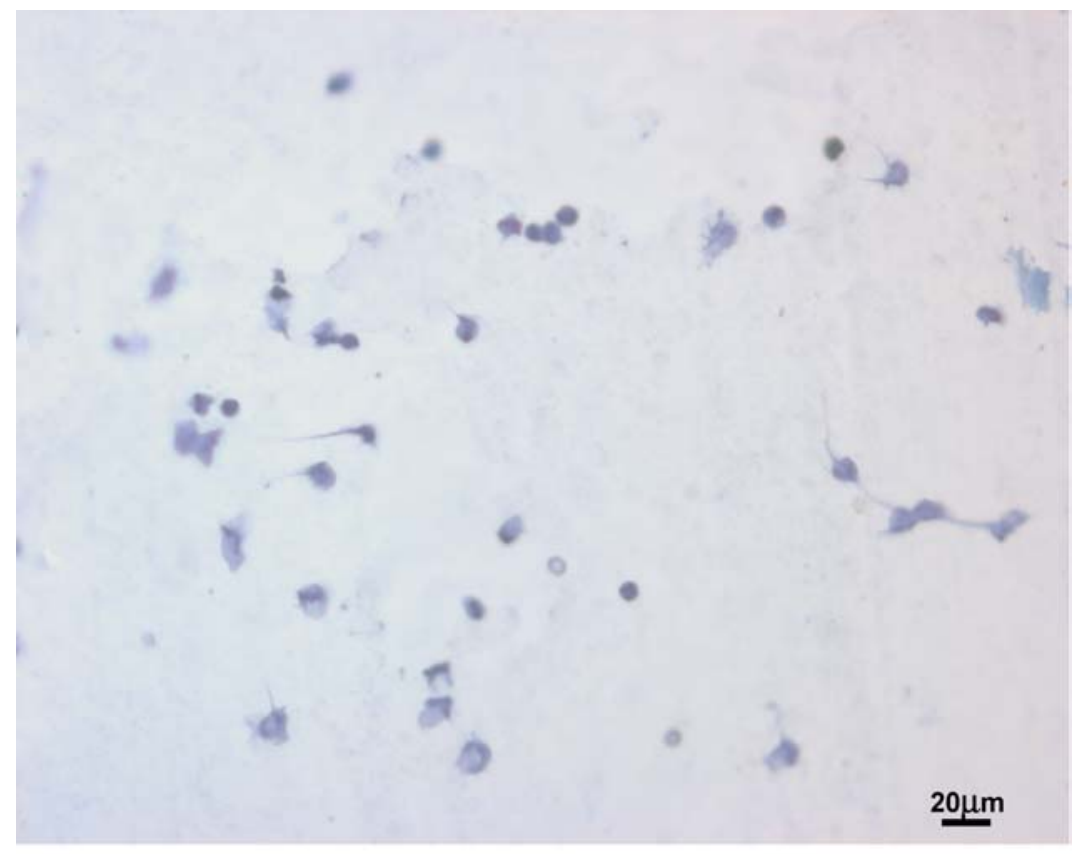

(a)

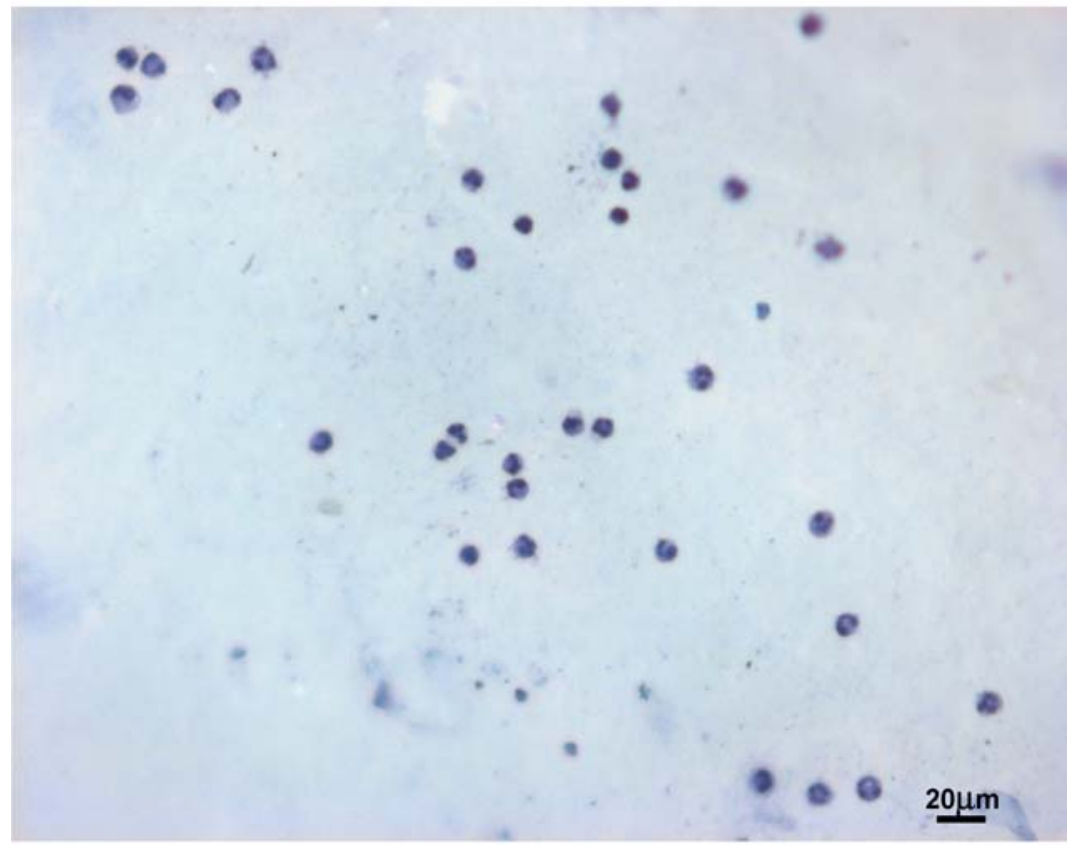

(b)

Figure 1 PMN cultured on the surface of starch-based polymers and stained with haematoxylin (X20). (a) SEVA-C after 2 h of culture; (b) SPCL after $4 \mathrm{~h}$ of culture; (c) SCA after $2 \mathrm{~h}$ of culture; (d) SEVA-C $+10 \% \mathrm{HA}$ after $2 \mathrm{~h}$ of culture; (e) SPCL+30\%HA after $4 \mathrm{~h}$ of culture; (f) SCA $+20 \% \mathrm{HA}$ after $2 \mathrm{~h}$ of culture. 


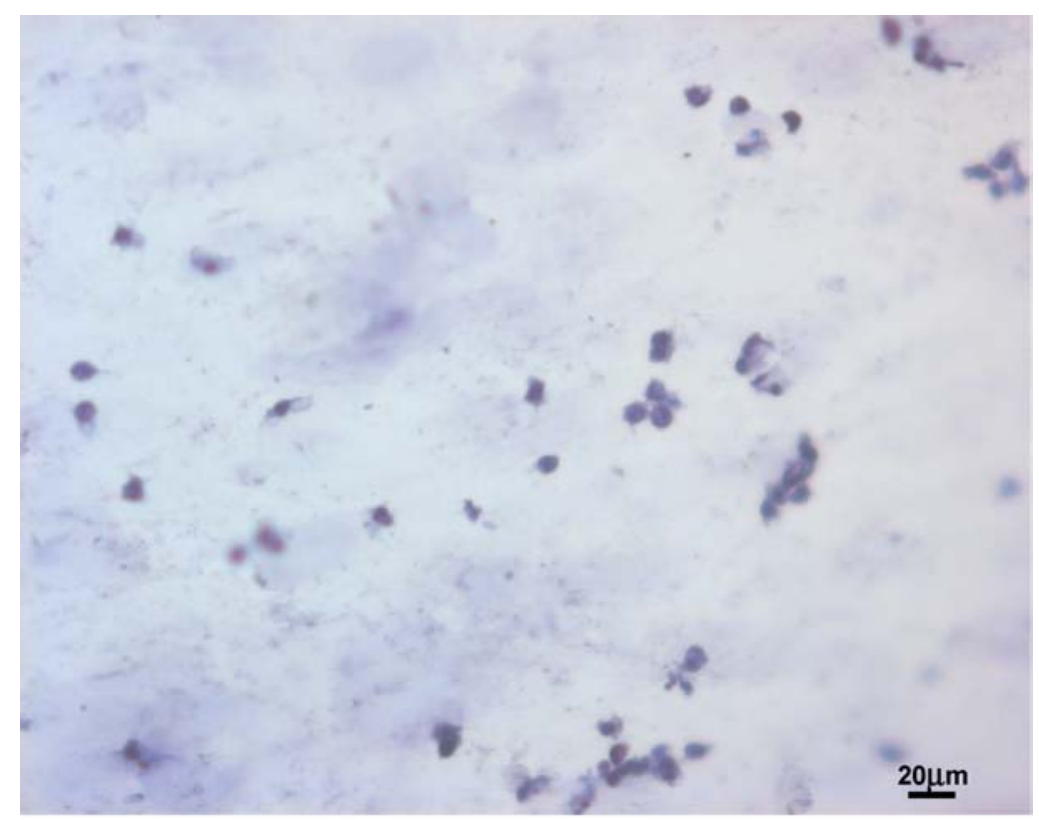

(c)

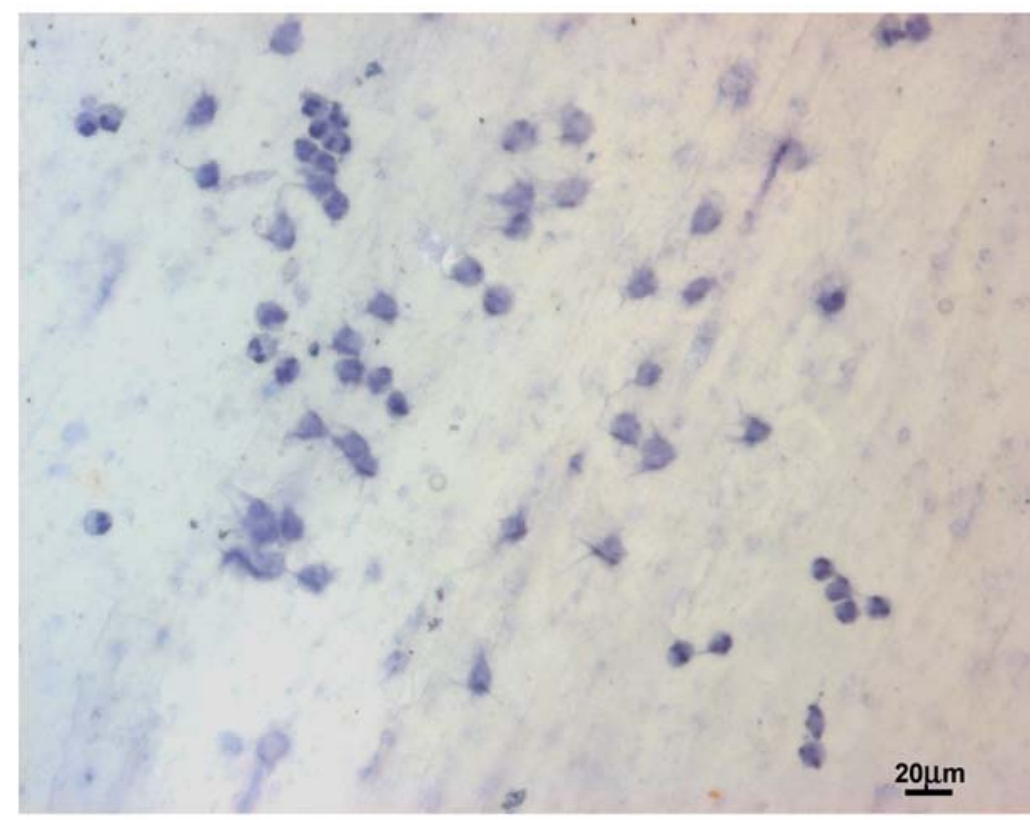

(d)

Figure 1 (Continued).

(Fig. 1(d)) and in the presence of 20 and $30 \%$ of HA, cells remained quite round.

For the starch-cellulose acetate materials, variations in the morphology of adherent cells were only observed in the presence of the composite with $20 \%$ ceramic (Fig. 1(f)) where it was possible to see some individual cells with extended filopodia. The unreinforced polymer and the composites with 10 and $30 \%$ of HA showed that neutrophils on these surfaces assumed a round morphology although with some spreading, having the tendency to agglomerate forming clusters.

For the starch-based blends with polycaprolactone there was only a percentage of HA that showed differences in neutrophil adhesion. For SPCL and it's composites with 10 and $20 \%$ of HA, cells presented a round morphology comparable to isolated cells (Fig. 1(b)) while in the composite with $30 \%$ of HA, adherent cells were bridging to other cells forming structure with a chain-like shape (Fig. 1(e)). It should be noted that these differences were observed after $4 \mathrm{~h}$ of culture since after $2 \mathrm{~h}$ they looked alike on the surface of any of the starch-polycaprolactone polymers or composite materials.

\subsubsection{Monocytes/macrophages and lymphocytes}

The SEM observation of the mixed mononuclear population of monocytes/macrophages and lymphocytes cultured in direct contact with the materials in study demonstrated that, in fact, the different types of cells present in culture were adhered to the different surfaces. Lymphocytes were identified by being much smaller in size than monocytes/macrophages and presented a very round morphology. The morphology of monocytes/macrophages varied depending on the 


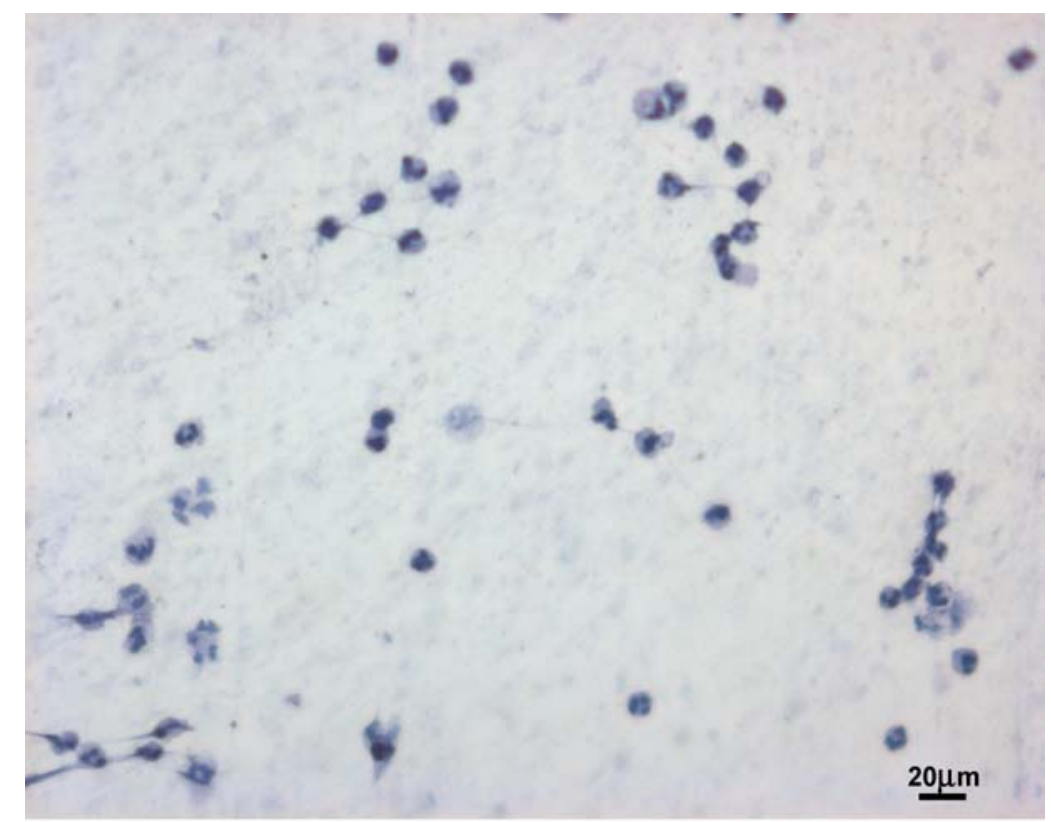

(e)

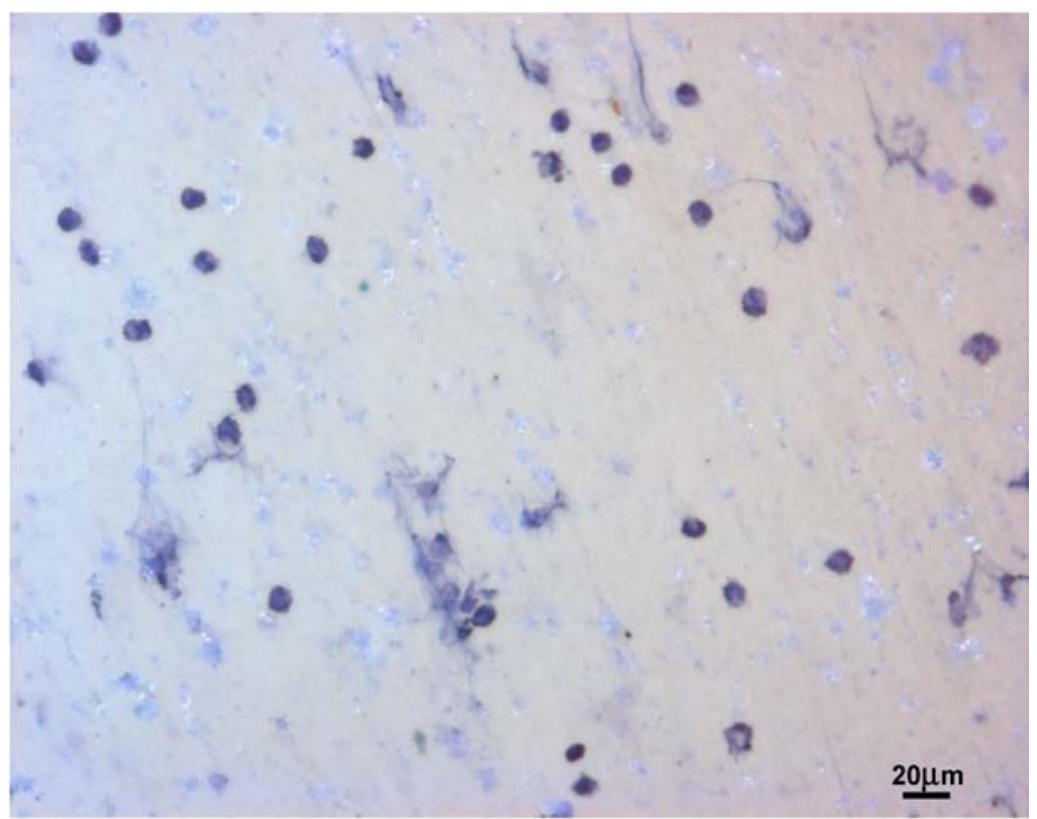

(f)

Figure 1 (Continued).

material. Non activated monocytes were round cells without filopodia and with many microvilli on the cell membrane surface. PLLA and PS were used as control materials; these materials presented a smooth surface, and it can be seen in Fig. 2(a) and 2(b) that cells showed cytoplasm extensions towards the materials surface. SCA and it's composites were found to be the surfaces where monocytes/macrophages spread out (Fig. 2(e)). The majority of the cells displayed long cytoplasmic extensions especially in the case of the unreinforced polymer. On the SCA composites, cells presented fine filopodia which seemed to be looking for the HA particles.

In contrast to starch-cellulose acetate materials, cells adherent to SPCL and it's composites were found to maintain a round morphology, comparable to non activated cells (Fig. 2(c)). Neither the presence of ceramic nor its amount affected cell adhesion.
Comparing all the materials, SEVA-C and its composites resulted in an intermediate mode of adhesion. It was possible to observe a considerable amount of monocytes/macrophages spread on these surfaces, although not showing significant filopodia. Cells were flattened on the surfaces using all of their cytoplasm instead of fine cell extensions (Fig. 2(d)).

The quantification of cells by LDH determined that SEVA-C and its composites were the surfaces that promoted more monocyte/macrophage and lymphocyte adhesion (Fig. 3(a)) and that for SCA and it's composites less cells adhered (Fig. 3(b)).

In considering all blends the results for unreinforced polymers and composites with $10 \%$ of HA were found to be similar as well as the results between the composites with 20 and $30 \%$ of ceramic. Thus, for each blend and considering the amount of adherent cells it was possible to divide the materials in two groups. For 
the materials based on starch-ethylene vinyl alcohol and starch-cellulose acetate (Fig. 3(a) and (b)) higher amounts of HA resulted in fewer adherent cells, while in the case of SPCL materials the opposite was verified (Fig. 3(c)).

The number of cells on the surface of SEVA-C and SCA materials was also found to increase from 3 to 7 days of culture and decrease from that time on, while in the case of materials of starch-polycaprolactone the number of cells tends to decrease from 3 days until the end of the experiment.

The number of cells on the surface of the control materials was equivalent to SCA and its composite with $10 \%$ of HA (Fig. 3(a) and (b)).

\subsection{Immunocytochemistry}

Although in vitro conditions may influence the functional behaviour of cells, this study was performed in order to correlate morphological observations and the functional activity of monocytes/macrophages and lymphocytes, in vitro, in the presence of novel potential biomaterials. Image analysis was attempted in order to quantify the number of cells expressing each antigen, however it was not possible to apply that technique since many details, apart from the cells, on the surface of starch-based materials were also stained which resulted in significant errors in the numbers obtained.

The surface markers on macrophages have shown modulated expression because of contact with materials (Table I). Our results highlighted the presence of distinct functional subsets of macrophages. These subsets exhibit morphological, immunophenotypic and functional differences depending on the polymer substrate. From SEM analysis, lymphocytes were quite easy to identify presenting a very round shape. This was confirmed from positive staining using CD3 (Fig. 4(a)) and CD5 antigens. Adherent lymphocytes on the surface of all the tested materials demonstrated that the expression of CD3 and CD5 was affected by the type of material

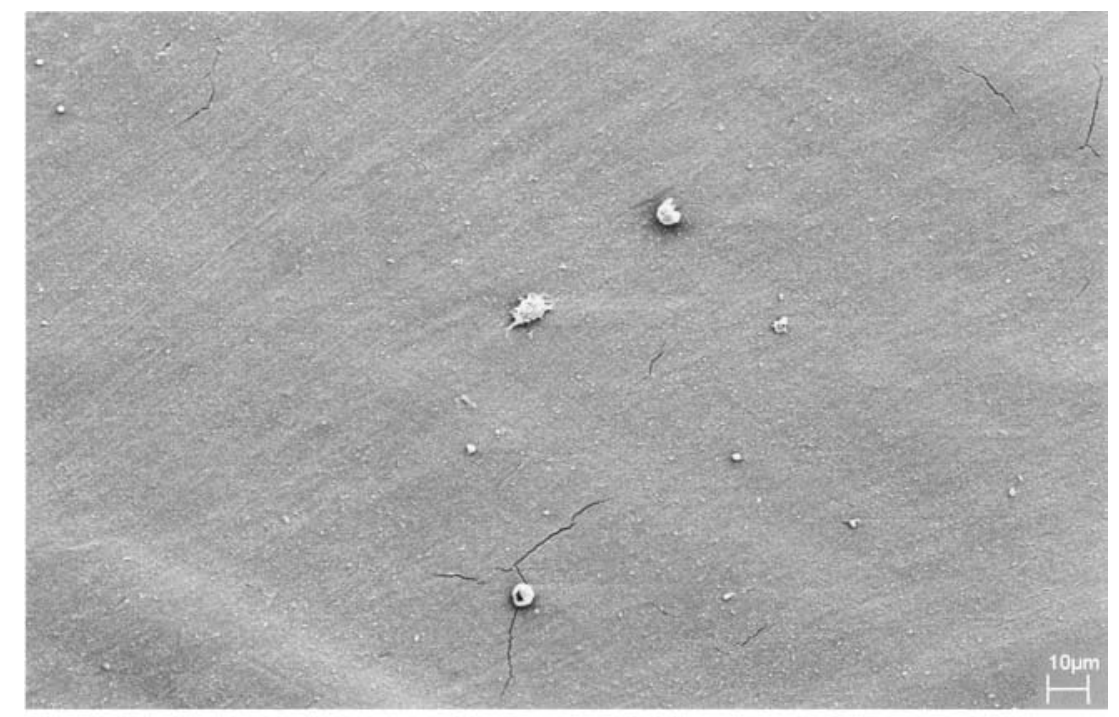

(a)

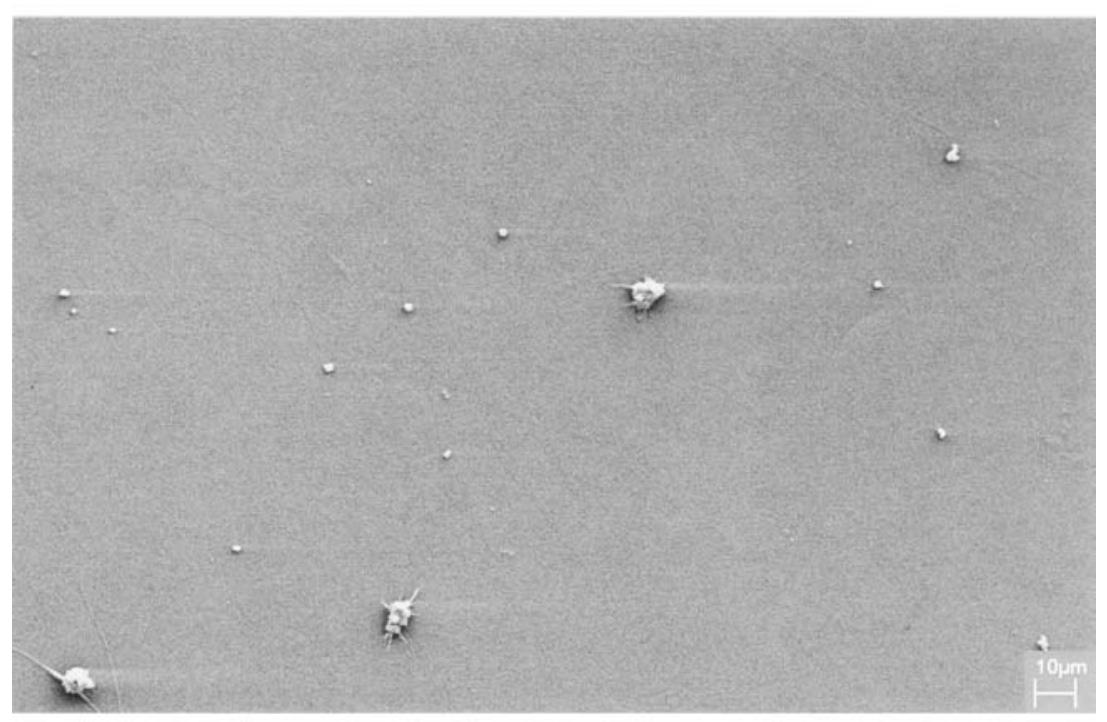

(b)

Figure 2 Scanning electron micrograph showing a mixed population of monocytes/macrophages and lymphocytes cultured on the surface of different polymers for 7 days. (a) PLLA; (b) PS; (c) SPCL; (d) SEVA-C; (e) SCA+30\%HA. 


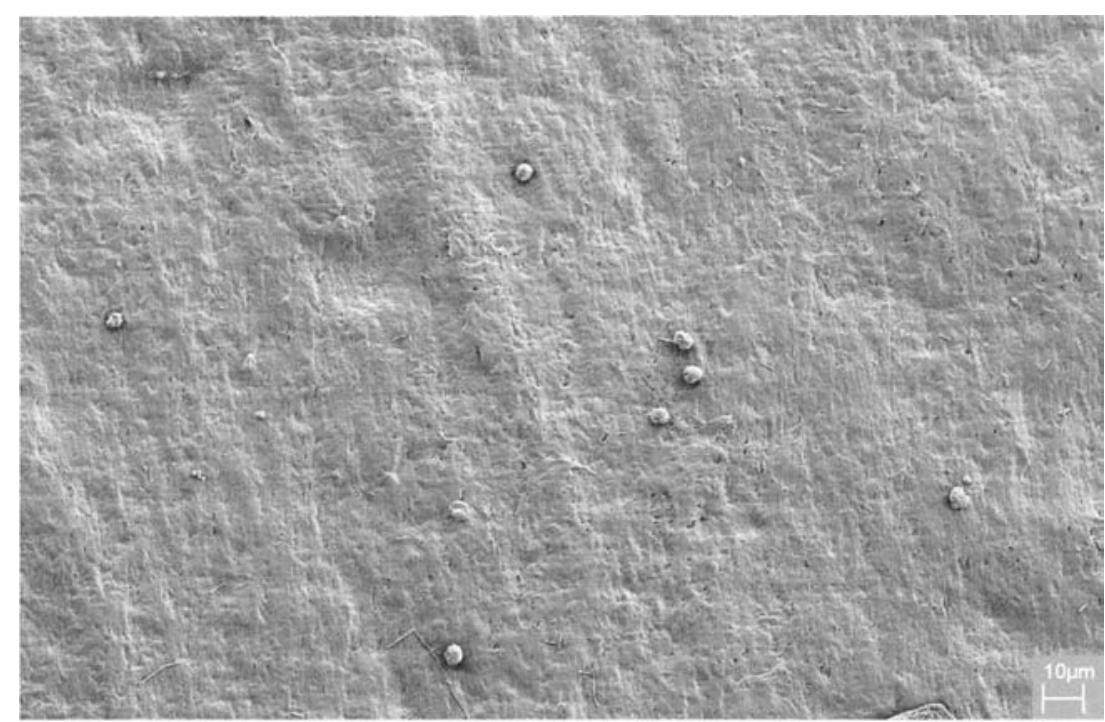

(c)

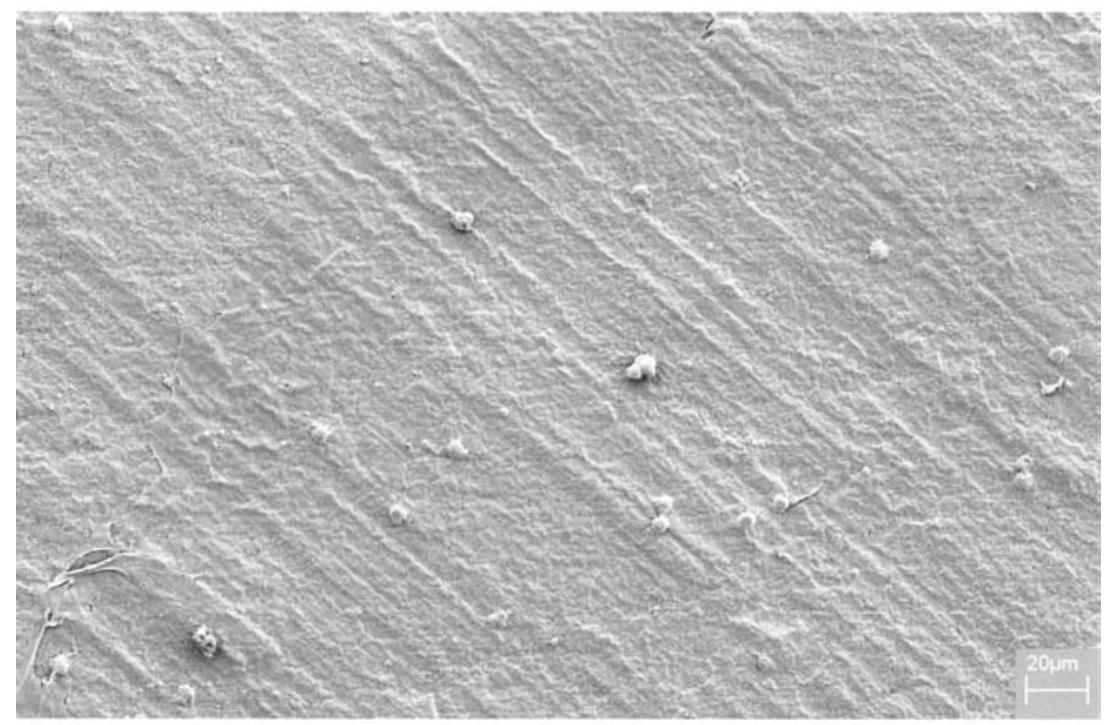

(d)

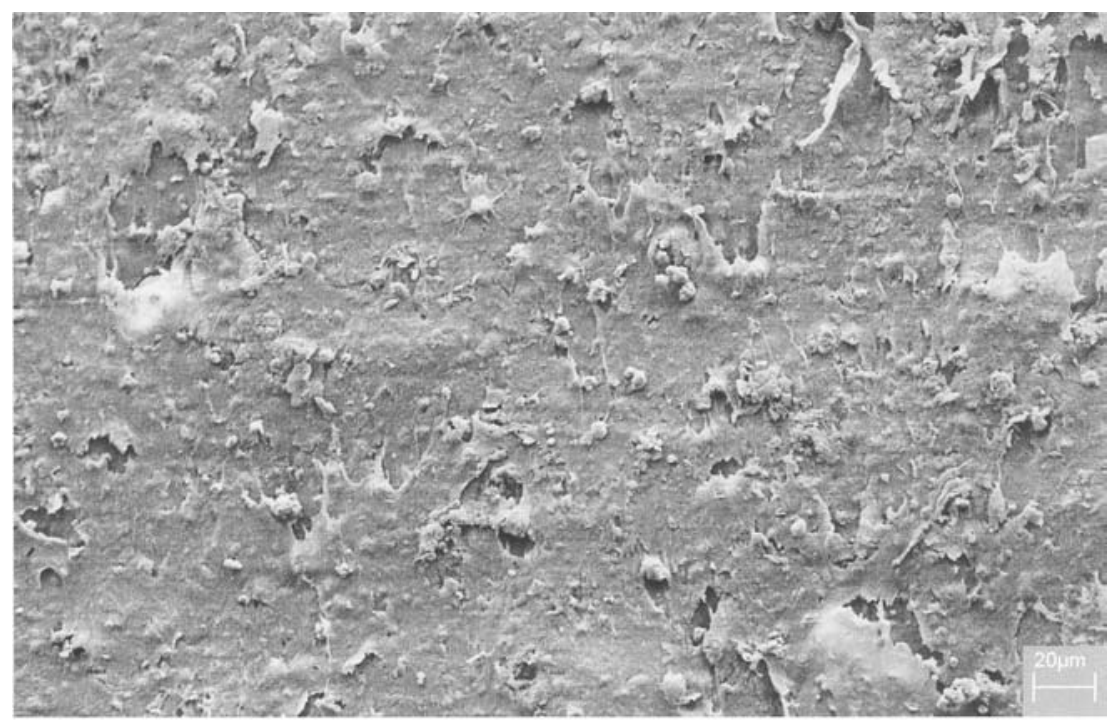

(e)

Figure 2 (Continued). 

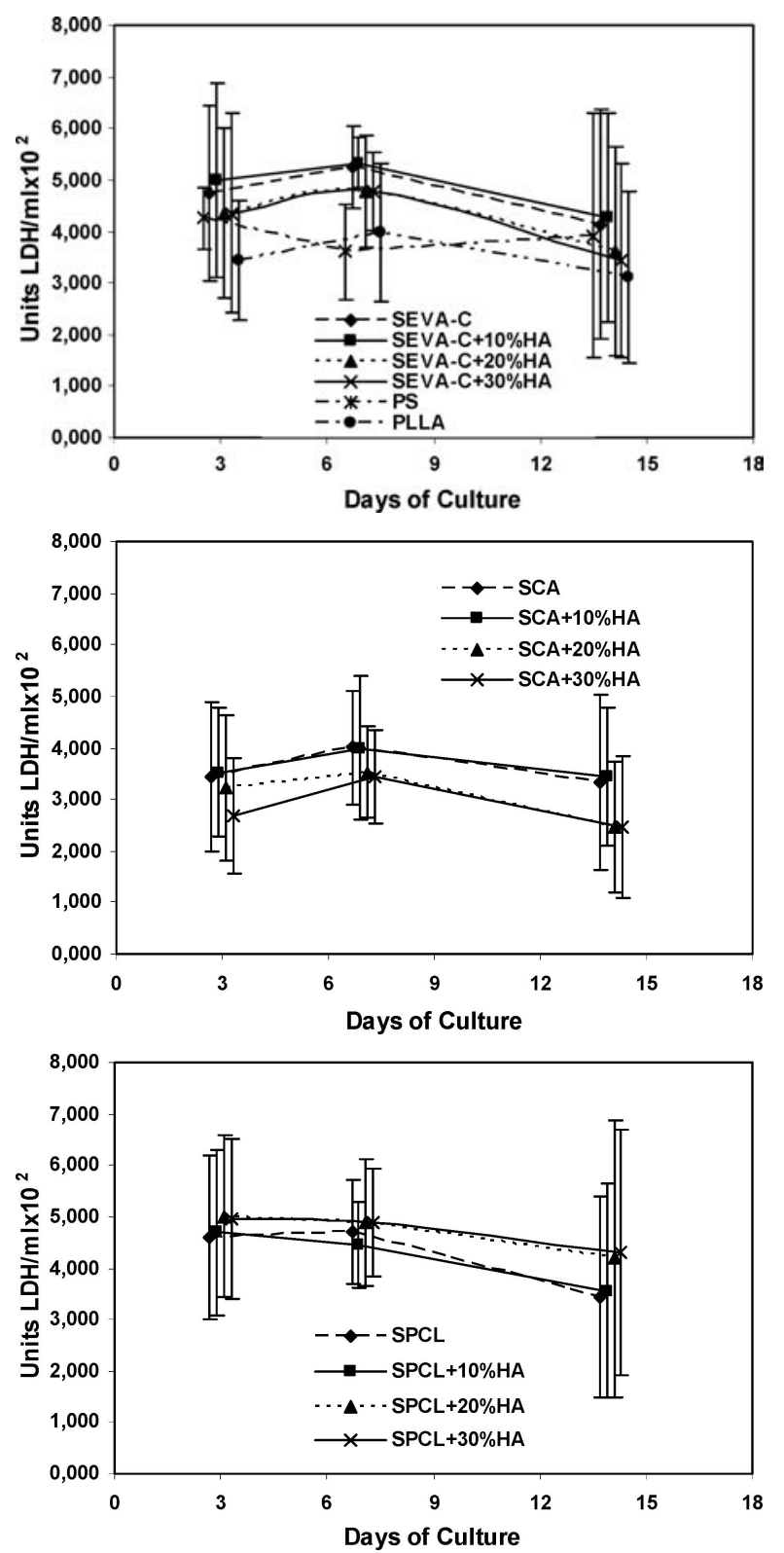

Figure 3 Concentration of lactate dehydrogenase (LDH) in the cell cytoplasm, from a mixed population of monocytes/macrophages and lymphocytes, adhered to the polymers and composites after 3, 7 and 14 of culture.

and for some materials, also by the time of culture. For the surfaces of PS and SPCL the number of CD3 positive lymphocytes seemed to decrease with time. Lymphocytes seemed to be present in higher numbers on the surface of PS and SPCL after 3 days of culture, decreasing to fairly similar amounts to the other materials after 7 days. In the case of the other materials the amount of cells expressing CD3 did not change significantly for longer periods of culture. Furthermore, for all the materials, the amount of CD5 positively stained cells did not significantly vary with increasing time. Moreover, the composites presented a similar number of cells expressing both CD3 and CD5 antigens, compared with the unreinforced polymer. It should be stressed that these statements are based on microscopical observations; the total number of cells on the surface of the materials does not vary as demonstrated by the statistical analysis of the LDH quantification.
The identification of the CD11/CD18 integrins expressed by leukocytes adhered to the surface of the different polymers by immunostaining with anti- LFA-1, Mac- 1 and CD11c antibodies, confirmed the existence of different sub-populations of cells. It was possible to identify CD11c positive macrophages as a subpopulation of cells, which spread according to substrata (Fig. 4(d)). Two other sub-sets of macrophages showing different levels of attachment/spreading were found to be CD11b positive (Fig. 4(c)). Cells stained with antiCD11a antibody confirmed the attachment of different cell types, lymphocytes and monocytes and the subpopulations of macrophages (Fig. 4(b)).

The culture time influenced the number of cells expressing CD11/CD18 molecules, although the numbers of mature macrophages (CD68 positive cells, Fig. 4(e)) also seemed to increase on PS and SPCL for longer culture periods. In the presence of PS and SEVA-C the number of $\mathrm{CD} 11 \mathrm{~b}$ positive cells appeared to increase with the time of culture. Furthermore for increasing time of culture, more cells expressing LFA-1 and CD11c, were found adherent to SEVA-C and SPCL respectively. An opposite tendency was presented by cells expressing CD11c after adherence to PLLA, which seem to be in lower amounts for longer times of culture.

The different materials in the study also affected the monocyte/macrophage phenotype. The number of macrophages (positive cells for CD11c) adherent to the surface of the PS is much higher than on any of the other polymers. In addition, PS, SCA and SPCL were also found to up-regulate the expression of Mac-1 when compared to SEVA-C and PLLA.

Another interesting result involves the presence of HA. The presence of the ceramic did not seem to affect CD11c expression in the cultured cells when comparing to unreinforced materials. However, although increasing amounts of HA did not seem to induce significant differences in the expression of CD11/CD18 adhesion molecules, it was possible to observe that the incorporation of the ceramic down-regulates Mac-1 expression on cellulose acetate and polycaprolactone containing composites and induces spreading on cells adherent to SCA composites and expressing LFA-1. Furthermore, CD68 antigen was found to be down-regulated in the presence of SEVA-C and SPCL composites when compared to the polymers without ceramic.

Considering the activation state of the cells cultured in contact with starch-based materials it was possible to observe that in fact, macrophages expressing CD54 (ICAM-1), showed a particular morphology when compared with other cells stained with different antibodies (Fig. 4(f)). Cells were shown to be well spread on the surface of the polymers and in lower numbers on SCA and PLLA. In addition, SEVA-C and SPCL composites induced a down regulation in ICAM-1 expression.

This study also demonstrates a significant difference in antigen-presenting phenotype in adherent cells. SEVA-C, PLLA and PS showed fewer cells expressing the HLA-DR antigen, however for longer culture times, the number of cells presenting antigen decreased for SEVA-C and increased for PLLA as well as for SCA. 
TABLE I Immunocytochemistry detection of surface molecules expression in a mixed population of lymphocytes and monocytes/macrophages, cultured with different polymers

\begin{tabular}{|c|c|c|c|c|c|c|c|c|c|}
\hline \multirow[b]{2}{*}{ Material } & \multirow[b]{2}{*}{ Culture time (days) } & \multicolumn{8}{|c|}{ Antibodies } \\
\hline & & CD3 & CD5 & CD11a & CD11b & CD11c & CD54 & CD68 & MHCII \\
\hline \multirow[t]{3}{*}{ SEVA-C } & 3 & + & + & + & + & + & ++ & ++ & ++ \\
\hline & 7 & + & + & + & + & + & ++ & ++ & + \\
\hline & 14 & + & + & ++ & ++ & + & ++ & ++ & + \\
\hline \multirow[t]{3}{*}{ SEVA-C $+10 \% \mathrm{HA}$} & 3 & + & + & + & + & + & + & + & ++ \\
\hline & 7 & + & + & + & + & + & + & + & ++ \\
\hline & 14 & + & + & + & + & + & + & + & ++ \\
\hline \multirow[t]{3}{*}{ SEVA-C $+20 \% \mathrm{HA}$} & 3 & + & + & + & + & + & + & + & ++ \\
\hline & 7 & + & + & + & + & + & + & + & ++ \\
\hline & 14 & + & + & + & + & + & + & + & ++ \\
\hline \multirow[t]{3}{*}{ SEVA-C $+30 \% \mathrm{HA}$} & 3 & + & + & + & + & + & + & + & ++ \\
\hline & 7 & + & + & + & + & + & + & + & ++ \\
\hline & 14 & + & + & + & + & + & + & + & ++ \\
\hline \multirow[t]{3}{*}{ SCA } & 3 & + & + & ++ & ++ & ++ & + & + & ++ \\
\hline & 7 & + & + & ++ & ++ & ++ & + & + & +++ \\
\hline & 14 & + & + & ++ & ++ & ++ & + & + & +++ \\
\hline \multirow[t]{3}{*}{$\mathrm{SCA}+10 \% \mathrm{HA}$} & 3 & + & + & + & + & ++ & + & + & + \\
\hline & 7 & + & + & + & + & ++ & + & + & + \\
\hline & 14 & + & + & + & + & ++ & + & + & + \\
\hline \multirow[t]{3}{*}{$\mathrm{SCA}+20 \% \mathrm{HA}$} & 3 & + & + & ++ & + & ++ & + & + & + \\
\hline & 7 & + & + & ++ & + & ++ & + & + & + \\
\hline & 14 & + & + & ++ & + & ++ & + & + & + \\
\hline \multirow[t]{3}{*}{$\mathrm{SCA}+30 \% \mathrm{HA}$} & 3 & + & + & + & + & ++ & + & + & ++ \\
\hline & 7 & + & + & + & + & ++ & + & + & ++ \\
\hline & 14 & + & + & + & + & ++ & + & + & ++ \\
\hline \multirow[t]{3}{*}{ SPCL } & 3 & ++ & ++ & ++ & ++ & + & ++ & ++ & ++ \\
\hline & 7 & + & ++ & ++ & ++ & + & ++ & ++ & ++ \\
\hline & 14 & + & ++ & ++ & ++ & ++ & ++ & +++ & ++ \\
\hline \multirow[t]{3}{*}{$\mathrm{SPCL}+10 \% \mathrm{HA}$} & 3 & + & + & ++ & + & + & + & + & ++ \\
\hline & 7 & + & + & ++ & + & + & + & + & ++ \\
\hline & 14 & + & + & ++ & + & + & + & + & ++ \\
\hline \multirow[t]{3}{*}{$\mathrm{SPCL}+20 \% \mathrm{HA}$} & 3 & + & + & ++ & + & + & + & + & ++ \\
\hline & 7 & + & + & ++ & + & + & + & + & ++ \\
\hline & 14 & + & + & ++ & + & + & + & + & ++ \\
\hline \multirow[t]{3}{*}{$\mathrm{SPCL}+30 \% \mathrm{HA}$} & 3 & + & + & ++ & + & + & + & + & ++ \\
\hline & 7 & + & + & ++ & + & + & + & + & ++ \\
\hline & 14 & + & + & ++ & + & + & + & + & ++ \\
\hline \multirow[t]{3}{*}{ PS } & 3 & ++ & + & ++ & ++ & +++ & ++ & ++ & + \\
\hline & 7 & + & + & ++ & ++ & +++ & ++ & ++ & + \\
\hline & 14 & + & + & ++ & +++ & +++ & ++ & +++ & + \\
\hline \multirow[t]{3}{*}{ PLLA } & 3 & + & + & ++ & + & ++ & + & ++ & + \\
\hline & 7 & + & + & ++ & + & ++ & + & ++ & ++ \\
\hline & 14 & + & + & ++ & + & + & + & ++ & ++ \\
\hline
\end{tabular}

+ -Sparse; ++ -Moderate; +++ -Abundant.

\section{Discussion}

Polymorphonuclear neutrophils are found at the surface of the materials $10 \mathrm{~min}$ after blood exposure and the cells become activated after $30 \mathrm{~min}$ to an extent that depends on the implanted device [26]. These cells may become activated either directly through adhesion receptors, or indirectly via platelet-derived mediators. However, the adhesion-mediated mechanisms of PMN activation are not well understood and several works [27-31] have shown conflicting results. Some studies $[29,30]$ presented evidence that cell adhesion has an important role in supporting or preventing neutrophil apoptosis. In addition, interactions between neutrophils and a biomaterial surface have been suggested to cause premature activation of cells which causes a long-term down-regulation of neutrophil function on biomaterial surfaces in vitro [28]. Other researchers [27, 31] have shown reduced oxidative responses from adherent PMNs on different surfaces. A correlation between cell spreading, pseudopodia formation and activation state was suggested by Wettero et al. [32]. Other authors [33] reported similar results although suggesting a dependence of cell adhesion for oxygen radical production.

A previous study with starch-based materials also revealed that the production of degradative enzymes and reactive oxygen species was reduced when in contact with those materials [31]. Based on this it could be suggested that SPCL and composites would not promote immediate neutrophil adhesion, which would result in a more intense short-term activation that would be reduced after adhesion.

Plasma and/or matrix proteins, which have the potential to modify the interactive effects of materials and cells [34-36], instantly become associated with biomaterials, in in vivo and in vitro (in the presence of serum) conditions. Proteins may however act in different ways. Some studies $[34,36]$ demonstrated that 
some proteins enhance neutrophil activation, but other research showed that they can inhibit PMN resulting in a diminished inflammation [34, 35]. The amount of protein pre-adsorbed on a surface can also affect cell adhesion by masking the surface properties of the underlying substrate and thus minimising the non-specific interactions [37]. Not only the type of proteins or their concentration, but also the way they adsorb to the materials is determinant for cell adhesion. This dependence ultimately relies on the physical and chemical nature of the surfaces. In fact, oxidised surfaces were shown to stimulate granulocyte activation [38]. Moreover, PMN were observed to use different receptors to adhere onto hydrophilic and hydrophobic surfaces [39].

The present in vitro study was performed in the presence of serum, a complex system of different proteins, which adsorb to the surface of the different materials and consequently modulate cell adhesion, depending on the material properties. Previous studies with starchbased blends showed that the three materials present a different surface in physical [20] and chemical terms [40]. In fact the SCA polymer, the material with higher
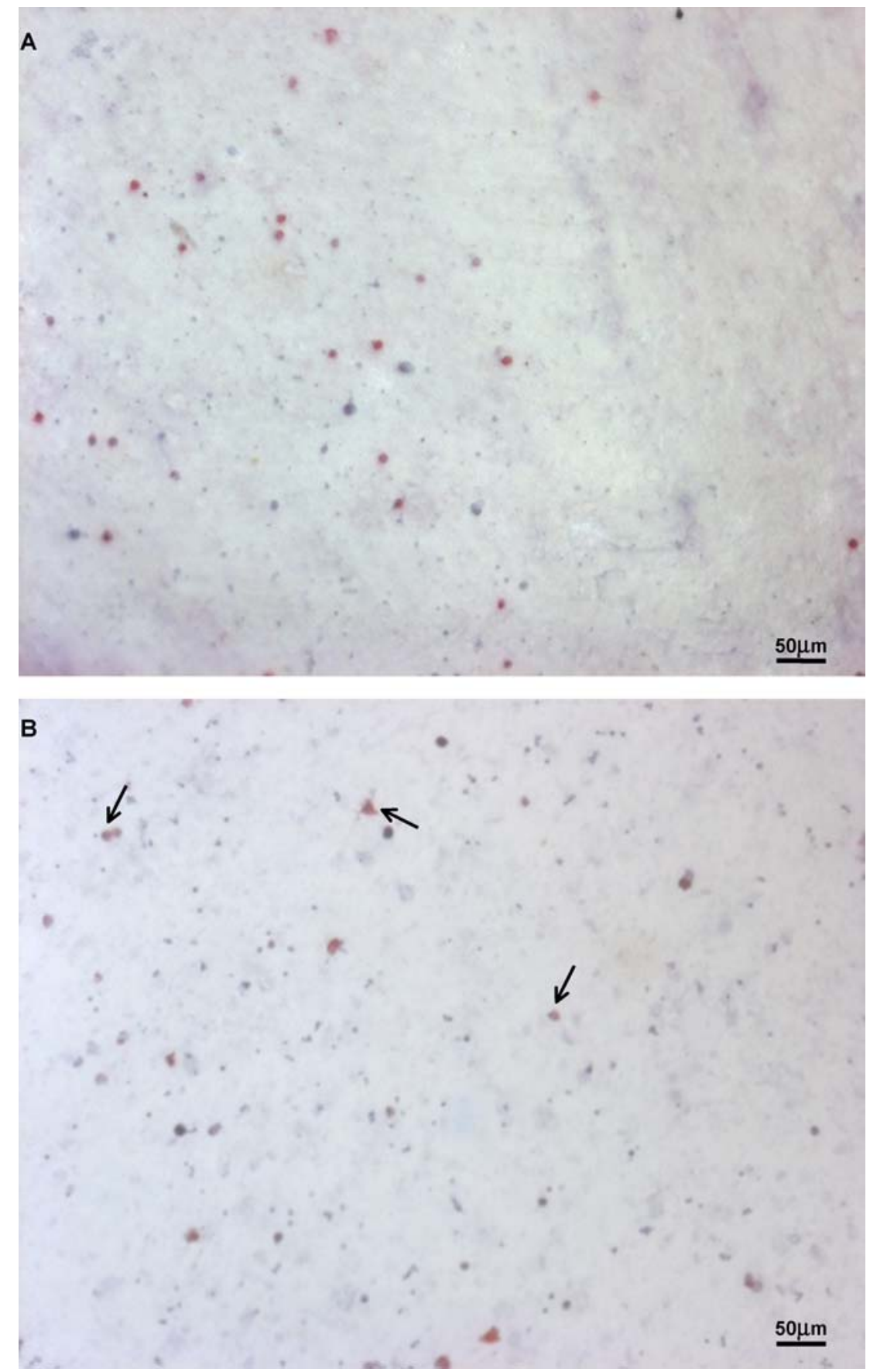

Figure 4 Immunostaining of mixed cell populations of monocytes/macrophages and lymphocytes cultured for 3 days (d), 7 days (a, b, f) and 14 days (c, e) on: (a) SEVA-C+20\%HA, (b) SCA+20\%HA; (c) SEVA-C, (d) SEVA-C+10\%HA, (e) PS, (f) PLLA. Cells were stained using CD3 (a), CD11a (b), CD11b (c), CD11c (d), CD68 (e) and CD54 (f) antibodies (red cells, arrows) and counterstained with haematoxylin (purple cells). Magnification $(\times 10)$. 

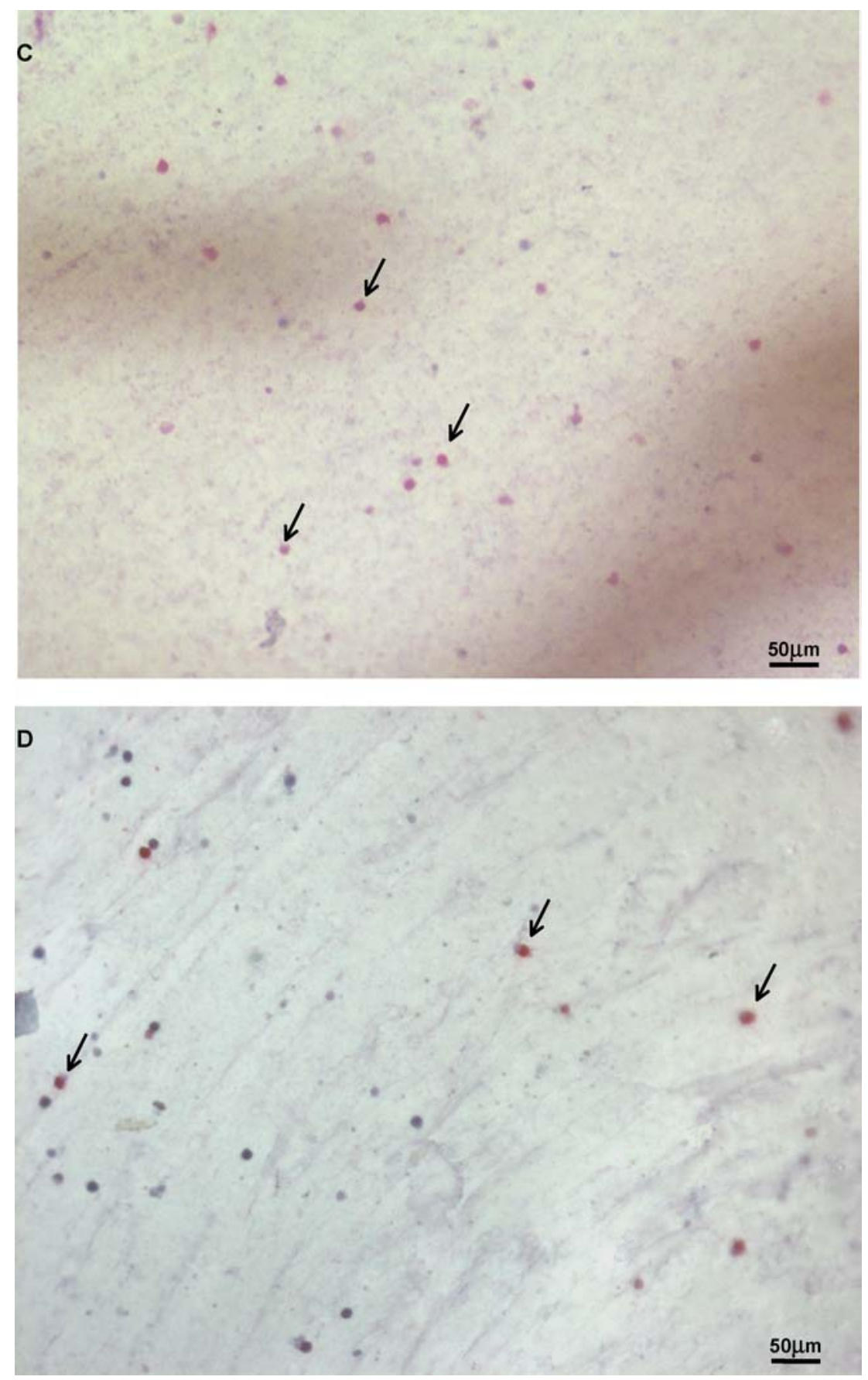

Figure 4 (Continued).

number of adhered PMNs, has a higher oxygen content on its surface [40].

It can also be speculated that the presence of HA influences neutrophil adhesion in highly (SCA) and moderate (SEVA-C) hydrophilic surfaces in different ways respectively inducing and reducing the number of adherent cells probably due to their wettability. The incorporation of ceramic reduces hydrophilicity which will reach a more favourable value in the case of SCA, but transforming SEVA-C to a less adherent surface for neutrophils.

Therefore considering the predisposition of each material in the study to attract PMNs, the morphology cells assume when adherent and the previously reported results on reactive oxygen production and degradative enzyme release in the presence of starch-based polymers, it can be suggested that starch-based materials that promote more neutrophil adhesion tend to inactivate PMN.

Contrarily to PMNs, macrophage lineage is known to be heterogeneous, with considerable variability in cell morphology [41, 42]. Morphologically, the cell increases in size, the number of cytoplasmic granules increases and the plasma membrane becomes more ruffled after activation. Phagocytic activity is also another characteristic that activated macrophages may exhibit upon attachment to a surface. Activated macrophages spread more rapidly and extensively than resting macrophages [43]. Therefore, cellular adhesion and spreading on material surfaces appears to be an 

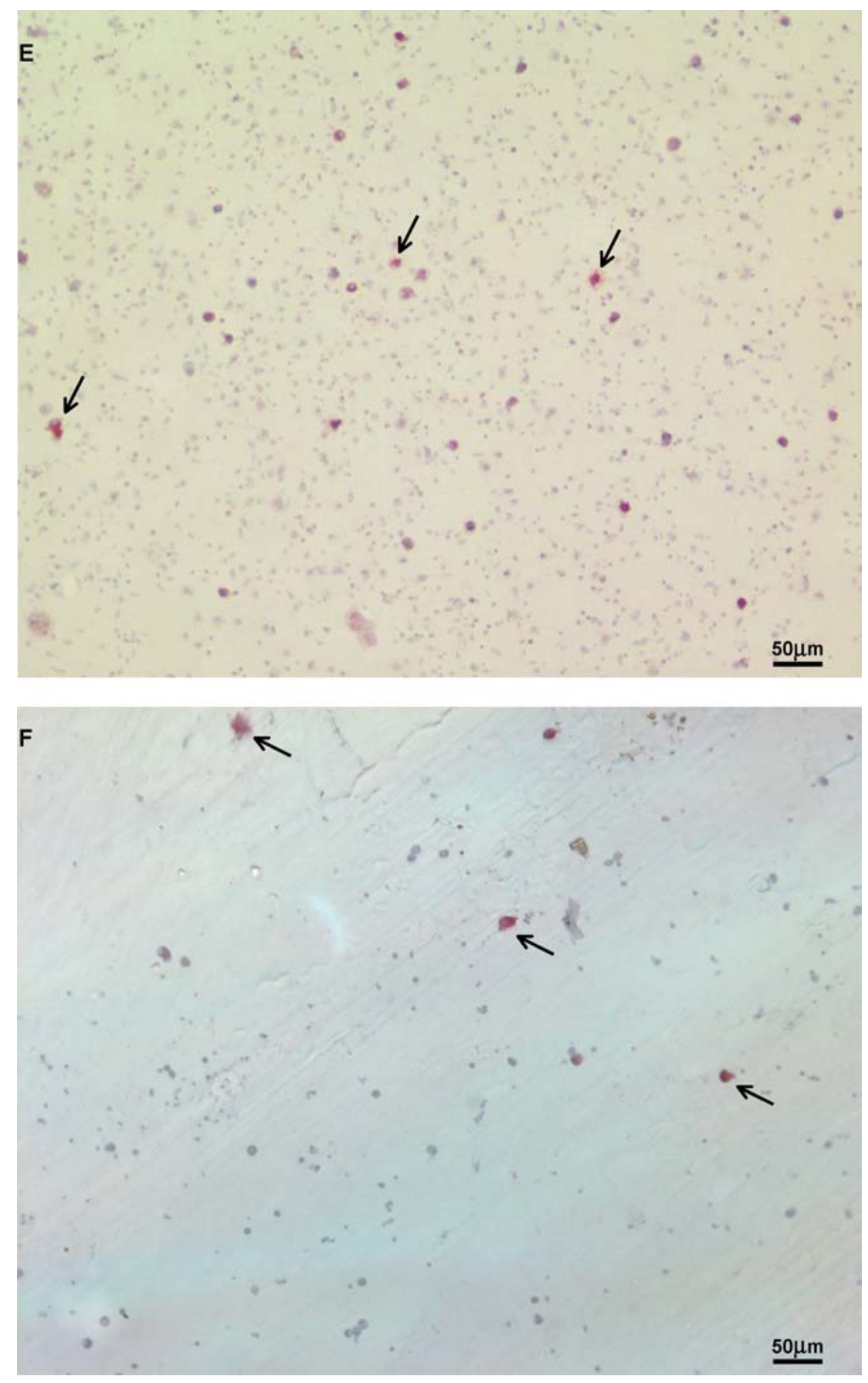

Figure 4 (Continued).

attempt by the macrophage to phagocytose the implanted device.

Some studies $[44,45]$ have focused on the capacity of macrophages to degrade ceramic coatings or to phagocytose HA particles through the extension of cytoplasmic pseudopodia around particles until completely encapsulated.

The lower numbers of cells in the presence of SEVA$\mathrm{C}$ and SCA composites and their tendency to decrease with increasing percentages of HA might suggest preferential monocyte/macrophage adhesion to ceramic particles when comparing to the surface of the polymers. It may be hypothesised that polymer/HA interfaces were more susceptible to degradation inducing the release of HA particles, which in turn attract the phagocytes therefore decreasing the number of cells on the surface of the materials.

There is some controversy about the factors that affect and how they affect leukocyte adhesion to biomaterials surfaces. Wettability and morphology of the materials were shown to play an important role; porous and more hydrophilic surfaces were found to have more adhered monocytes [46, 47] but some authors [48-50] have concluded that macrophages preferentially accumulate on rough and hydrophobic surfaces in vitro. Considering each one of these variables independently, we could say that from our study monocyte/macrophages and lymphocytes adhere in similar amounts to more hydrophobic (SPCL) and to moderately hydrophilic (SEVA-C) surfaces and do not adhere 
preferentially to rougher substrates since SCA is the polymer with the most irregular surface [51].

However, not only those properties of the surfaces of biomaterials are known to affect monocyte/macrophage adhesion and activation. Since these cells bear a negative charge due to their lipoprotein membrane structure therefore inhibiting cell adhesion to negatively charged surfaces, it was suggested that electrostatic forces might influence leukocyte adhesion. Furthermore Anderson et al. [47] identified the potential of surface chemistry-dependent conformational alterations, which may occur in proteins adsorbed to surfaces. Specific fibronectin fragments are potent chemoattractants for human blood monocytes, while the intact molecule is not chemotactically active [52]. On the other hand, surfaces that preferentially adsorb vitronectin from serum containing medium are favourable for macrophage adhesion [53, 54]. A previous study with starch-based materials showed that from human serum, vitronectin adsorbs onto starch-ethylene vinyl alcohol based materials and that more monocytes/macrophages and lymphocytes were present at short times of culture on these surfaces [55]. The results in the present study (performed in culture medium containing serum), are in accordance with that work since SEVA-C and composites were the materials that showed higher cell adhesion, which suggests a possible mediation of vitronectin in monocyte/macrophage and lymphocyte adhesion to that starch-based blend.

In the presence of biomaterials, leukocyte integrins undergo an activation process during which changes in affinity (conformation) and avidity (post-receptor occupancy) can up-regulate ligand-binding activity. Conformationally sensitive integrin binding with specific adsorbed peptide sequences is believed to provide anchorage and stimulate signal transduction pathways of adherent cells in a surface dependent manner [56].

Mac-1 (CD11b/CD18) plays a key role in the adherence of both monocytes and neutrophils to vascular endothelium and has been implicated in the evaluation of cell activation [57-59]. CD11b/CD18 expressing cells are also known to be involved in the phagocytosis. Following stimulation CD11b/CD18 is rapidly mobilised from intracellular stores to the cell membrane and although an increase in receptor expression of CD11b/CD18 can result in increased cell adhesion it was previously suggested that not all newly recruited receptors are believed to be functional [59]. Instead, further modifications are needed in order to render the receptors functionally competent thus, the expression of CD11b/CD18 cannot fully predict the degree of cell activation [57, 58].

Allying a hypothetical activated state of the CD11b/ CD18 positively stained cells with their phagocytic role it might be possible to identify, from the cells adherent to the surface of the materials in study, those which are in fact activated. The sub-type of monocytes/macrophages expressing CD11b/CD18 with a larger spread morphology characteristic of cells that are involved in the phagocytosis process can be presumed to correspond to those activated cells.
The Intracellular Adhesion Molecule-1 (ICAM-1) is used in vitro as a marker of activation [43, 60] and also suggested [43] that its expression at the surface of the cell may be linked more with the extent of cell spreading than to the concentration of soluble inducers. Therefore, the materials that presented lower number of cells expressing ICAM-1 molecules (SCA and PLLA) are expected to induce less short-term inflammation.

Probably a little unexpected was the fact that the expression of ICAM-1 did not seem to be affected by the time of culture. It would be natural the maturation/activation of monocytes/macrophages in an in vitro system where cells are exposed to foreign materials. The presence of HA down-regulates the maturation of monocytes into macrophages that some composites down-regulates the expression of ICAM-1 molecules together with the expression of CD11b/CD18 integrins.

Polymers can induce a specific immune response in two ways mainly; releasing products that bind adequate tissue carriers and become antigenic or altering selfproteins, which can be endocytosed and presented by APCs to T cells $[61,62]$. The results for MHCII identification could be explained by considering that SCA is the material that takes up more water and consequently degrades more rapidly. It is possible that the surface changes not only from the materials but also in terms of adsorbed proteins, with the time of culture resulting in increased activity from antigen-presenting cells. The amount of activated macrophages (CD54 positive) was found to be lower in the presence of SCA, which was not in agreement with the results for antigen-presenting cells identification.

\section{Conclusions}

An in vitro model was established simulating aspects of the in vivo inflammatory response. The aim was to evaluate individual and collective cellular effects resulting from the interaction of the different populations of inflammatory cells with starch-based biodegradable biomaterials.

The inflammatory response to biomaterials was demonstrated to be a very complex process, certainly influenced by the chemical and physical properties of the materials. These factors did not necessarily act independently and also affected the diverse components of the biological system in different ways.

While SCA promoted higher PMN adhesion and lower activation, the number of cells from a mixed population of monocytes/macrophages and lymphocytes was found to be lower on that material also showing a reduced amount of activated macrophages. In addition, the hydroxyapatite reinforcement induced changes in cell behaviour for some materials but not for others. However, HA generally showed reduced monocytes/macrophage adhesion and less potential to activate the cells.

Comparing the control materials, there was no significant difference between the biodegradable materials; that is between starch-based and PLLA biomaterials. It was possible to verify that PS was from the tested polymers the one that showed the greatest inflammatory potential. 


\section{Aknowledgments}

The authors gratefully acknowledge the Portuguese Foundation for Science and Technology (FCT) and the Portuguese Programme PRAXIS XXI for awarding a PhD Grant to A. P. Marques (SFRH/BD1276/2000).

This work was also partially supported by FCT Foundation for Science and Technology, through funds from the POCTI and/or FEDER programmes.

\section{References}

1. J. M. ANDERSON, ASAIO Trans. 34 (1988) 101.

2. Y. T. KONTTINEN, J. W. JU, H. PATIALA, S. IMAI, V. WARIS, T. F. LI, S. B. GOODMAN, L. NORDSLETTEN and S. SANTAVIRTA, Curr. Orthop. 11 (1997) 40.

3. G. Voggenteiter, S. Leiting, H. BRAUER, P. LEITING, M. MAJETSCHAK, M. BARDENHEUER and U. OBERTACKE, Biomaterials 24 (2003) 247.

4. J. A. HUNT, K. R. ABRAMS and D. F. WILliams, Anal Cell Pathol. 7 (1994) 43.

5. P. Thomsen and C. GRetzer, Curr. Opin. Solid State Mater. Sci. 5 (2001) 163.

6. F. LiOTE, B. BOVAL-BOIZARD, D. WEILl, D. K UNTZ and J. L. W A U TIER, Clin. Exp. Immunol. 106 (1996) 13.

7. H. PELTROCHE-LLACSAHUANGA, S. SCHMidT, N. SCHNITZLER, R. LUTTICKEN and G. HAASE, J. Immunol Meth. 258 (2001) 13.

8. S. M. ALBELdA and C. A. B UCK, Faseb J. 4 (1990) 2868.

9. M. STEWART, M. THIEL and N. HOGG, Curr. Opin. Cell. Biol. 7 (1995) 690.

10. S. D. WRIGHT, P. E. RAO, W. C. VAN VOORHIS, L. S. CRAigmyle, K. LidA, M. A. TAlle, E. F. WESTBERG, G. GOLDSTEIN and S. C. SILVERSTEIN, Proc. Natl. Acad. Sci. USA 80 (1983) 5699.

11. H. V. NIELSEN, J. P. CHRISTENSEN, E. C. ANDERSSON, O. MARKER and A. R. THOMSEN, J. Immunol. 153 (1994) 2021.

12. M. A. ARNAOUT, Blood. 75 (1990) 1037.

13. A. MEA GER, Cytokine Growth Factor Rev. 10 (1999) 27.

14. L. W. POUlTER, D. A. CAMPBEll, C. MUNRO and G. JANOS S Y, Scand. J. Immunol. 24 (1986) 351.

15. F. G. GiAnCOtti and C. G. GAHMBERG, Curr. Opin. Cell. Biol. 9 (1997) 643.

16. R. L. REIS, A. M. CUNHA and M. J. BEVIS, J. Appl. Med. Polym. 2 (1998) 49.

17. R. L. REIS and A. M. CUNHA, J. Appl. Med. Polym. 4 (2000),

18. P. B. MAlafaya, C. Elvira, A. GAllardo, J. SAN ROMAN and R. L. REIS, J. Biomed. Sci. Polym. Edn. 12 (2001) 1227.

19. I. ESPIGARES, C. ELVIRA, J. F. MANO, B. VÁZQUEZ, J. SAN ROMAN and R. L. REIS, Biomaterials 23 (2002) 1883.

20. M. E. GOMES, J. S. Godinho, D. TCHALAMov, A. M. CUNHA and R. L. REIS, Mat. Sci. Eng. C. 20 (2002) 19.

21. S. C. MENDES, R. L. REIS, Y. P. BOVELL, A. M. CUNHA, C. A. VAN BLITTERSWIJK and J. D. DE B R UIJN, Biomaterials 22 (2001) 2057.

22. M. E. GOMES, R. L. REIS, A. M. CUNHA, C. A. BLITTERSWIJK and J. D. DE BRUIJN, Biomaterials 22 (2001) 1911

23. A. P. MARQUES, R. L. REIS and J. A. HUNT, Biomaterials 23 (2002) 1471.

24. R. L. REIS, S. C. MENDES, A. M. CUNHA and M. J. B E V IS , Polym. Int. 43 (1997) 347.

25. P. R. KINNEARD and C. D. GRAY, in "SPSS for Windows: Made Simple" (Psychology Press, Hove, 1999).

26. H. NYGREN, C. ERIKSSON and J. LAUSMAA, J. Lab. Clin. Med. 129 (1997) 35

27. S. T. HOFFSTEIN, D. E. GENNARO andR. M. MANZI, Lab. Invest. 52 (1985) 515.

28. S. S. KAPLAN, R. E. BASFORD, M. H. JEONG and R. L. SIMMONS, J. Biomed. Mater. Res. 30 (1996) 67.
29. I. GINIS and D. V. FA LLER,Am. J. Physiol.272(1997) C295.

30. B. WALZOG, F. JEBLONSKI, A. ZAKRZEWICZ and P. GAEHT GENS, FASEB J. 11 (1997) 1177.

31. A. P. MARQUES, R. L. REIS and J. A. HUNT, J. Mater. Sci. Mater. Med. 14 (2003)167.

32. J. WETtERO, T. BENGTSSON and P. TENGVALL, $J$. Biomed. Mater. Res. 51 (2000) 742.

33. L. LIU, H. ELWING, A. KARLSSON, G. NIMERI and C. DAHLGREN, Clin. Exp Immunol. 109 (1997) 204.

34. C. F. NATHAN, Blood. 73 (1989) 301

35. C. NATHAN, Q. W. XIE, L. HALBWACHSMECARELLi and W. W. JIN, J. Cell. Biol. 122 (1993) 243.

36. C. DE LA CRUZ, B. HAIMOVICH and R. S. GRECO, J. Surg. Res. 80 (1998) 28.

37. V. A. TEGouliA and S. L. CoOper, J. Biomed. Mater. Res. 50 (2000) 291.

38. F. RENÒ, F. LOMBARDI and M. CANNAS, Biomaterials 24 (2003) 2895.

39. C. ERIKS S ON and H. NYGREN, J. Lab. Clin. Med.137 (2001) 296.

40. I. PAShKuleva, A. P. MARQues, F. VAZ and R. L. REIS, J. Mater. Sci. Mater. Med. in press (2003).

41. S. GESSANI, U. TESTA, B. VARANO, P. DI MARZIO, P. BORGHI, L. CONTI, T. BARBERI, E. TRITARELli, R. MARTUCCI, D. SERIPA et al., J. Immunol. 151 (1993) 3758.

42. M. BENAHMED, H. BLOTTIERE, V. PRALORAN and G. DACULS I, Biomaterials 15 (1994) 25.

43. S. F. BERNATCHEZ, M. R. ATKINSON and P. J. PARKS, ibid. 18 (1997) 1371.

44. T. W. BAUER, R. C. GEESINK, R. ZIMMERMAN and J. T. MCMAHON, J. Bone. Joint. Surg. Am. 73 (1991) 1439.

45. L. NORDSLETTEN, A. K. HOGASEN, Y. T. KONTTINEN, S. SANTAVIRTA, P. ASPENBERG and A. O. AASEN, Biomaterials 17 (1996) 1521.

46. T. H. YOUNG, D. T. LIN and L. Y. CHEN, J. Biomed. Mater. Res. 50 (2000) 490.

47. J. M. ANDERSON, K. DEFIFE, A. MCNALly, T. COLlier and C. R. JENNEY, J. Mater. Sci. Mater. Med. 10 (1999) 579.

48. A. RICH and A. K. HARRIS, J. Cell. Sci. 50 (1981) 1.

49. D. W. MURRAY, T. RAE and N. RUSHTON, J. Bone. Joint. Surg. Br. 71 (1989) 632.

50. C. ERIKSSON, J. LAUSMAA and H.-. NYGREN, Biomaterials 22 (2001) 1987.

51. A. P. MARQUES, I. B. LEONOR, R. L. REIS and J. HUNT, in 28th Annual Meeting of The Society for Biomaterials (Tampa, Florida, USA, 2002) p. 647.

52. D. A. NORRIS, R. A. CLARK, L. M. SWIGART, J. C. HUFF, W. L. WESTON and S. E. HOWELL, J. Immunol. 129 (1982) 1612.

53. C. H. Thomas, J. B. Lhoest, D. G. CASTNER, C. D. MCFARLAND and K. E. HEALY, J. Biomech. Eng. 121 (1999) 40.

54. C. R. JENNEY and J. M. ANDERSON, J. Biomed. Mater. Res. 49 (1999) 435.

55. C. M. ALVES, R. L. REIS and J. A. HUNT, J. Mater. Sci: Mater. Med. 14 (2003) 157.

56. F. G. GiAnCOTti, Curr. Opin. Cell. Biol. 9 (1997) 691.

57. N. B. VEDDER and J. M. HAR L A N, J. Clin. Invest. 81 (1988) 676.

58. M. R. PHILIPS, J. P. BUYON, R. WinChESTER, G. WEISSMAN and S. B. ABRAMSON, ibid. 82 (1988) 495.

59. M. S. DIAMOND and T. A. SPRINGER, J. Cell. Biol. 120 (1993) 545.

60. M. L. Dustin, R. ROthlein, A. K. Bhan, C. A. DINARELLO and T. A. SPRINGER, J. Immunol. 137 (1986) 245.

61. D. F. Williams, J. Mater. Sci. 22 (1987) 3241.

62. B. Rihova, Adv. Drug. Deliver. Rev. 21 (1996) 157.

Received 27 May 2004

and accepted 11 March 2005 